\title{
Psychosocial impact of COVID-19 on the Brazilian elderly population
}

\section{Impacto psicosocial de COVID-19 en la población brasileña de edad avanzada}

DOI: $10.46932 / \mathrm{sfjdv2n4-023}$

Received in: May 1st, 2021

Accepted in: Jun 30th, 2021

\section{Larissa Pinheiro de Castro}

Graduate student in Neuropsychology and Rehabilitation Celso Lisboa University Center (UCL), Rio de Janeiro, Rio de Janeiro, Brazil

E-mail: psi.larissapdecastro@gmail.com

\section{Lúcia Aparecida de Souza}

Specialist in Chemical Dependence, Alcohol and Drug Research Unit, Federal University of São Paulo

(UNIFESP), São Paulo, São Paulo, Brazil

E-mail: luciasouzasocial@gmail.com

Hortência Gueve da Fonseca

Specialization student in Psychosocial Care for Victims of Violence, University of Federal University of São Carlos (UFSCAR), São Carlos, São Paulo, Brazil

E-mail: hortenciafonseca2016@gmail.com

João Gabriel Modesto

Undergraduate student in Interdisciplinary Bachelor of Health, Federal University of Bahia (UFBA),

Salvador, Bahia, Brazil

E-mail: jgmodesto15@gmail.com

\section{Marília Lopes Pernambuco}

Graduate in Pharmacy, Master in Public Health, Federal University of Ceará (UFC), CEP 60020-181, Fortaleza, Ceará, Brazil

E-mail: marilialopes_p@yahoo.com.br

Clara Mariana Gonçalves Lima

$\mathrm{PhD}$ student in Food Science, School of Food Engineering University of Campinas (UNICAMP),

Campinas, São Paulo, Brazil

E-mail: claramarianalima@gmail.com

Jorge Pamplona Pagnossa

$\mathrm{PhD}$ in Agricultural Microbiology, Department of Biology, Federal University of Lavras (UFLA)

Lavras, Minas Gerais, Brazil

E-mail: jorgepampa@gmail.com

\begin{abstract}
COVID-19 is a highly contagious disease caused by the new betacoronavirus of severe acute respiratory syndrome 2 (SARS-CoV-2). The high mortality of the disease occurs in a small portion of the infected population, especially in elderly individuals. The main measure adopted in Brazil to contain the virus is social isolation and this can have an impact on the mental health of the elderly population. This study
\end{abstract}


aims to provide an educational intervention, understanding the repercussions that the COVID-19 pandemic has on the routine of the elderly. This is a study carried out through documentary analysis, based on bibliographic reviews, national and international, of specialists in the subject. It was found that mandatory social isolation causes uncertainties, insecurity, fear, and sometimes low self-esteem, which can lead to an emotional imbalance during this period of the pandemic of the new coronavirus, causing the elderly to become more fragile. Therefore, it is important to give special attention to this group based on specific health plans during this period together with the relatives of these elderly, which will enable better results in coping with COVID-19 in this group, besides preventing a spike in the incidence of mental health-related diseases.

Keywords: Elderly. COVID-19. Mental Health.

\section{RESUMEN}

La COVID-19 es una enfermedad altamente contagiosa causada por el nuevo betacoronavirus del síndrome respiratorio agudo severo 2 (SARS-CoV-2). La elevada mortalidad de la enfermedad se produce en una pequeña parte de la población infectada, especialmente en individuos de edad avanzada. La principal medida adoptada en Brasil para contener el virus es el aislamiento social y esto puede tener un impacto en la salud mental de la población anciana. Este estudio tiene como objetivo proporcionar una intervención educativa, entendiendo las repercusiones que la pandemia de COVID-19 tiene en la rutina de los ancianos. Se trata de un estudio realizado a través de un análisis documental, basado en revisiones bibliográficas, nacionales e internacionales, de especialistas en el tema. Se constató que el aislamiento social obligatorio provoca incertidumbres, inseguridad, miedo y, a veces, baja autoestima, lo que puede llevar a un desequilibrio emocional durante este período de la pandemia del nuevo coronavirus, provocando la fragilidad de los ancianos. Por lo tanto, es importante dar una atención especial a este grupo en base a planes de salud específicos durante este período junto con los familiares de estos ancianos, lo que permitirá obtener mejores resultados en el afrontamiento de la COVID-19 en este grupo, además de evitar un repunte en la incidencia de enfermedades relacionadas con la salud mental.

Palabras clave: Ancianos. COVID-19. Salud mental.

\section{INTRODUCTION}

COVID-19 is a highly contagious disease caused by the new betacoronavirus of severe acute respiratory syndrome 2 (SARS-CoV-2). This infection was characterized by the World Health Organization (WHO) as a pandemic due to the overall proportion of the outbreak that occurred in the first half of 2020. The high mortality of the disease occurs in a small portion of the infected population, especially in elderly, immunosuppressed, cardiac, and hypertensive individuals. Many infected are asymptomatic (and may be carriers) or have mild to moderate symptoms, similar to the flu state. The clinical picture of COVID-19 in the most severe form is characterized by an inflammatory storm of cytokines, with hematological and coagulation alterations that can lead to tissue damage and death (Xavier et al., 2020). 
The infection mainly affects the upper respiratory tract similar to a simple cold but may compromise the lower respiratory tract (Guo et al, 2020). The incubation period after exposure to infection can vary from two to 14 days ( $\mathrm{Li}$ et al., 2020). The first patients reported common prodromal symptoms of infection, such as fever, cough, fatigue, and myalgia. These may be accompanied by respiratory secretions, headache, and diarrhea, and complications of the infection can lead to SARS-CoV-2-related pneumonia and cardiac or renal impairment, secondary infection, and shock (Huang et al., 2020). Coronaviruses (CoVs) are 60 to $130 \mathrm{~nm}$ in diameter surrounded by a lipoprotein layer and contain a singlestrain ribonucleic acid (RNA) genome, ranging from 26 to 32 kilobases $(\mathrm{Kb})$ in length (Schoeman \& Fielding, 2019; Cascella et al., 2020). This virus presents pleomorphic capsids and surface projections the spicules - in crown form, hence the name coronavirus (Cascella et al., 2020).

Due to the similarity of $96.2 \%$ RNA with coronavirus infecting horseshoe bats (Rhinolophus sp.), this mammal is considered the host of origin of the new coronavirus. In addition to having a similarity of $79.5 \%$ with the genetic code of SARS-CoV, the molecular mechanism of infection observed in human COVID-19 is the same, which involves the connection of the spicule, located on its surface, to the angiotensin-converter enzyme 2 (ACE- 2), acting as a cellular receptor for the virus (Guo et al., 2020; Zhu et al., 2020).

Recent studies show that children have a lower amount of angiotensin-converter 2 enzyme (ACE2) in the nasal epithelium than older individuals, which may confer some protection against SARS-CoV2 input cells at this vulnerable site for infection and transmission, and explain its lower incidence of COVID-19 (Bunyavanich et al., 2020). It is important to emphasize that even the occurrence of COVID19 cases is lower in children, these can carry the virus to other people becoming a spreading agent of the disease as well as any individual.

In this context, gaps in the prevention of contagion reinforce the importance of social isolation and hygiene measures, even in the absence of clinical manifestations. The transmission of viral particles between individuals is related to viral load in the upper respiratory tract and may occur by droplets of cough, sneezing, and saliva, handshake or objects of manual reach, such as cell phones, door handles, cups, and keys, with subsequent contact with mucous membranes (Ge et al., 2013, Zhu et al., 2020, Van Doremalen et al., 2020).

The main measure adopted in Brazil to contain the virus and reduce the chances of contamination is social isolation and this can have an impact on the mental health of the elderly population since isolation is necessary and mandatory during the pandemic. However, for some elderly, such a measure may be a triggering factor for psychiatric diseases or an aggravating factor, especially for those elderly living in long-term care institutions. In general, these elderly people are already of advanced age, chronic diseases, 
and difficulties performing their activities of daily living, have frequent contact with visits of family members, caregivers and maintain the habit of living in agglomerations (Nunes et al., 2020).

Thus, the pandemic of the new coronavirus has seen a tragedy already announced, since we are short of ensuring comprehensive and equitable care as recommended by the single health system (SUS). Considering the different forms of people's needs and realizing that almost $80 \%$ of the Brazilian population is dependent on the public health system, there is concern regarding the demand for health resources before, during, and after the pandemic. It is a consensus that the pandemic will pass, however, its impacts will be significant concerning the production of care.

Several studies of previous respiratory viral diseases reported in a proportion of patients, during and after hospital discharge, the presence of psychiatric conditions such as depression, anxiety, and posttraumatic stress disorder (del Busto et al., 2020). COVID-19, although a predominantly respiratory disease, some cases have also presented other features, including neurological symptoms and cognitive alterations.

Many psychosocial factors are associated with the risk of infection and hospitalization by COVID19, but the lower cognitive function has been pointed out as the most relevant factor (Batty et al., 2020). Cognitive deficits and executive dysfunctions can also be observed in a range of psychiatric conditions, such as depression, schizophrenia, posttraumatic stress, and neurodevelopmental disorders, as can also be found in cases of dementia and traumatic brain injury (Ardila \& Lahiri, 2020).

Aging, of course, is associated with a gradual decline in cognitive functions, even in the absence of neurological disease. So, it is common for elderly patients to present difficulties in performing and completing mental tasks, deficits in memory, attention, and executive functions. The COVID-19 pandemic may further aggravate the vulnerability of elderly patients, especially those who already have some cognitive impairment (Alonso-Lana et al., 2020).

Symptoms that may arise against the background of an acute viral infection, or after variable periods after infection. In addition to being associated with various psychiatric outcomes, these symptoms may be correlated with possible cognitive deficits, especially in the elderly population - the group that is at higher risk of developing the most severe form of the disease, due to factors associated with aging itself and a higher prevalence of clinical comorbidities and, therefore, more vulnerable to complications. (Alonso-Lana et al., 2020).

Several case reports that suggest the occurrence of cognitive deficits in patients with COVID-19, during and after the hospital discharge period, have mainly pointed out problems with memory, attention, confusion and the speed of information processing. These neuropsychological impairments may also suggest the existence of executive dysfunctions. Executive functions (EF's) are a set of cognitive processes 
necessary to direct behavior to the fulfillment of goals and objectives, persist in tasks that require concentration, and resistance to distractions and temptations. It is important to highlight that there are three main functions, which are: working memory, inhibiting control, and cognitive flexibility, and that their combinations, result in other more complex skills, called high-order EFs, such as the ability to reason, plan and make decisions. (Diamond, 2013).

Previous studies (Sasannejad et al., 2019; Riordan et al., 2020) point out that survivors of Severe Acute Respiratory Syndrome (SARS), especially those who have been on mechanical ventilation, may be susceptible to the development of long-term neurocognitive deficits. Besides, the most impaired functions include attention, short-term memory, which is directly related to the processing of working memory, which requires the retention of short-term memory information for efficient manipulation and executive functioning.

Dysexecutive syndromes can be identified from various behavioral manifestations, ranging from apathy to disinhibiting behavior, or to impairment of one or more cognitive domains, such as operational memory deficits, inattention, ineffective planning, and the ability to control impulses. An observational study with patients affected by Severe Acute Respiratory Syndrome (SRAG) due to COVID-19 identified the prevalence of dysexecutive syndrome in one-third (15 out of 45) of patients after hospital discharge, with symptoms of inattention, confusion, and disorientation, and poorly organized movements in response to commands (Helms et al., 2020).

The findings in the literature regarding cognitive deficits in patients with COVID-19, even in those recovered, raise the hypothesis that it is a consequence of inflammatory changes or the ability of the virus to invade the Central Nervous System, which consequently compromises cell viability and brain function. The exact pathophysiology of neurological complications remains unknown, but currently, the following mechanisms are proposed: that there is a direct viral invasion of the nervous system, autoimmune sequels, hypoxia-mediated lesions, and sequels of pro-inflammatory state (Riordan et al., 2020).

Some studies have linked this process to increased levels of cytokines in the most severe cases, the so-called "cytokine storms". Increased levels of inflammatory cytokines usually present in the most severely affected patients and are associated with neuronal death, deficiencies in synaptic plasticity, dysfunction in neurotransmitter metabolism, and the hypothalamic-pituitary-adrenocortical (HPA) axis. (Raony et al., 2020).

Chronic systemic inflammation has already been studied as one of the underlying pathogenic mechanisms involved in neurodegenerative diseases. A longitudinal study (Walker et al., 2019) studied systemic inflammation using a composite score of blood biomarkers with a sample of 12,336 participants with a mean age of 56.8 years. After a 20-year follow-up period, the result indicated a significant 
association between basal inflammation and accelerated cognitive decline. The growing evidence and understanding of the impact of the SARS-CoV-2 virus on the Central Nervous System then raise important questions about the impact of the risk of cognitive decline in adulthood, Alzheimer's disease, and other dementias.

In addition to age, conditions of social vulnerability, mental health, and lower cognitive capacity have also been related to the risk of contracting COVID-19, as they reduce the precautions taken to minimize the risk of contamination, to know and perceive health problems, and to seek medical attention. Communication with healthcare professionals may also be ineffective. A lower level of education can also influence the development of cognitive deficits; this means that elderly people with lower education have a higher proportion of cognitive deficits compared to those with a higher school level (Batty et al., 2020; Araújo Júnior et al., 2019).

Socioeconomic inequalities expose this population to risk circumstances, such as the use of public transportation, poor hygiene, and basic sanitation conditions and health services, a greater number of people living in the same house, difficulty maintaining social isolation without losing work or the main source of income (Barbosa et al., 2020). For the elderly already weakened in a situation of vulnerability, necessary actions can guarantee the protection of life and the maintenance of their integrality, human dignity, and autonomy.

Low socioeconomic status is also considered a variable that is directly related to higher systemic levels of inflammatory markers, which may explain how a lower social support network is associated with psychiatric symptoms in patients infected with the new coronavirus. Considering the high risk of negative health outcomes in older individuals, it is important to evaluate and investigate whether COVID-19 can trigger cognitive decline and executive dysfunctions in this vulnerable group since the identification of pre-existing cognitive impairment challenges clinical management and the result of possible longitudinal studies. This means that the true cognitive impact of the SARS-CoV-2 virus will be known after a distinction between patients with pre-infection cognitive impairment and patients who developed new

cognitive symptoms after infection.

Long-term complications in patients who have survived COVID-19 infection are currently unknown in their entirety, for this reason, survivors may be observed in the coming months or years and should be evaluated periodically with comprehensive neuropsychological and neuropsychiatric evaluations. It is necessary to think about the continuity of care to those who were severely affected by COVID-19, as well as those who had suspension in the follow-up of care for other diseases, as well as chronic conditions that were not assisted during the pandemic. 
Mendes (2020) states that the post-pandemic period has been considered as a moment of a "new normal", although it has not been precisely defined what this might mean. Since predictability is a human condition, it is necessary to have a minimum of prediction for the future, even in these uncertain conditions, and for this, it is necessary to discuss in various areas the impact of the pandemic on the lives of people and in the health system.

People are transformed with the experiences they have and from this, it is possible to problematize and propose strategies of change, in the perspective of a new way of producing care. The pandemic will provide this possibility of reverberating new care processes and from there the need to expand spaces for discussions to dialogue about the impacts of this experience. Feuerwerker (2014) states that it is in the micropolitics of learning, caring, and producing knowledge that movements of disaccommodation, displacement, and re-accommodations in all processes can be produced.

Therefore, mandatory social isolation causes uncertainties, insecurity, fear, and sometimes, low self-esteem. These factors contribute even more to prevent the elderly from gathering themselves with friends and family or leave home to perform some activity they desire (parties, religious services, games, etc.) This is a concern that can lead to an emotional imbalance during this period of the pandemic of the new coronavirus, causing the elderly to become more fragile.

In this case, it is important to give special attention to this group based on specific health plans during this period together with the relatives of these elderly, so they can return, as soon as possible, with a normal routine. Finally, adequate rest, avoiding excessive negative information in social networks, performing playful and creative activities such as painting, reading, listen to music, or any other activity that the elderly can perform within their physical capacity until this atypical moment is overcome.

\section{CONCLUSION}

The COVID-19 pandemic affected the global population in the most diverse aspects, and the elderly had a severe influence in psychosocial conditions. The major concern about mental health comes from social isolation, a necessary measure to prevent the spread of the virus. Thus, a reinforcement in care, following safety countermeasures, avoiding harmful situations, and ideal conditions of overcoming this period must be a priority. 


\section{REFERENCES}

Alonso-Lana, S., Marquié, M., Ruiz, A., \& Boada, M. (2020). Cognitive and neuropsychiatric manifestations of COVID-19 and effects on elderly individuals with dementia. Frontiers in Aging Neuroscience, 12, 1-15.

Araújo Júnior, F. B., Machado, I. T. J., Santos-Orlandi, A. A. D., Pergola-Marconato, A. M., Pavarini, S. C. I., \& Zazzetta, M. S. (2019). Fragilidade, perfil e cognição de idosos residentes em área de alta vulnerabilidade social. Ciência \& Saúde Coletiva, 24, 3047-3056.

Ardila, A., \& Lahiri, D. (2020). Executive dysfunction in COVID-19 patients. Diabetes \& Metabolic Syndrome: Clinecal Rsearch \&Reviews, 14(5), 1377-1378.

Barbosa, I. R., Galvão, M. H. R., Souza, T. A. D., Gomes, S. M., Medeiros, A. D. A., \& Lima, K. C. D. (2020). Incidence of and mortality from COVID-19 in the older Brazilian population and its relationship with contextual indicators: an ecological study. Revista Brasileira de Geriatria e Gerontologia, 23(1), 200171.

Batty, G. D., Deary, I. J., Luciano, M., Altschul, D. M., Kivimäki, M., \& Gale, C. R. (2020). Psychosocial factors and hospitalisations for COVID-19: prospective cohort study based on a community sample. Brain, Behavior, and Immunity, 89, 569-578.

Bunyavanich, S., Do, A., \& Vicencio, A. (2020). Nasal gene expression of angiotensin- converting enzyme 2 in children and adults. Jama, 323(23), 2427-2429.

Cascella, M., Rajnik, M., Cuomo, A., Dulebohn, S. C., \& Di Napoli, R. (2020). Features, evaluation and treatment coronavirus (COVID-19). StatPearls [Internet], 1-55.

Del Busto, J. E. B., Pedroso, M. D. M., Castellón, R. L., \& Toledo, L. H. (2020). Manifestaciones psiquiátricas en relación con la infección por el SARS-CoV-2. Anales de la Academia de Ciencias de Cuba, 10(3), 1-9.

Diamond, A. (2013). Executive functions. Annual Review of Psychology, 64, 135-168.

Feuerwerker, Laura Camargo Macruz. Micropolítica e saúde: produção do cuidado, gestão e formação (2014). Tese de Doutorado. Universidade de São Paulo.

Ge, X. Y., Li, J. L., Yang, X. L., Chmura, A. A., Zhu, G., Epstein, J. H., ... \& Shi, Z. L. (2013). Isolation and characterization of a bat SARS-like coronavirus that uses the ACE2 receptor. Nature, 503(7477), 535-538.

Guo, Y. R., Cao, Q. D., Hong, Z. S., Tan, Y. Y., Chen, S. D., Jin, H. J., .. \& Yan, Y. (2020). The origin, transmission and clinical therapies on coronavirus disease 2019 (COVID-19) outbreak-an update on the status. Military Medical Research, 7(1), 1-10.

Helms, J., Kremer, S., Merdji, H., Clere-Jehl, R., Schenck, M., Kummerlen, C., ... \& Meziani, 
F. (2020). Neurologic features in severe SARS-CoV-2 infection. New England Journal of Medicine, 382(23), 2268-2270.

Huang, C., Wang, Y., Li, X., Ren, L., Zhao, J., Hu, Y., ... \& Cao, B. (2020). Clinical features of patients infected with 2019 novel coronavirus in Wuhan, China. The Lancet, 395(10223), 497-506.

Li, Q., Guan, X., Wu, P., Wang, X., Zhou, L., Tong, Y., ... \& Feng, Z. (2020). Early transmission dynamics in Wuhan, China, of novel coronavirus-infected pneumonia. The New England Journal of Medicine, 382(13), 1199-1207.

Mendes, Eugênio Vilaça. "O lado oculto de uma pandemia: a terceira onda da Covid-19 ou o paciente invisível." (2020).

Nunes, V. M. D. A. (2020). COVID-19 e o cuidado de idosos: recomendações para instituições de longa permanência, Natal, RN : EDUFRN, 2020. 66 p.

Raony, Í., de Figueiredo, C. S., Pandolfo, P., Giestal-de-Araujo, E., Oliveira-Silva Bomfim, P., \& Savino, W. (2020). Psycho-neuroendocrine-immune interactions in COVID-19: potential impacts on mental health. Frontiers in Immunology, 11, 1170.

Riordan, P., Stika, M., Goldberg, J., \& Drzewiecki, M. (2020). COVID-19 and clinical neuropsychology: A review of neuropsychological literature on acute and chronic pulmonary disease. The Clinical Neuropsychologist, 34(7-8), 1480-1497.

Sasannejad, C., Ely, E. W., \& Lahiri, S. (2019). Long-term cognitive impairment after acute respiratory distress syndrome: a review of clinical impact and pathophysiological mechanisms. Critical Care, 23(352), $1-12$.

Schoeman, D., \& Fielding, B. C. (2019). Coronavirus envelope protein: current knowledge. Virology Journal, 16(1), 1-22.

Van Doremalen, N., Bushmaker, T., Morris, D. H., Holbrook, M. G., Gamble, A., Williamson,

B. N., ... \& Munster, V. J. (2020). Aerosol and surface stability of SARS-CoV-2 as compared with SARSCoV-1. New England Journal of Medicine, 382(16), 1564-1567.

Xavier, A. R., Silva, J. S., Almeida, J. P. C., Conceição, J. F. F., Lacerda, G. S., \& Kanaan, S. (2020). COVID-19: clinical and laboratory manifestations in novel coronavirus infection. Jornal Brasileiro de Patologia e Medicina Laboratorial, 56, 1-9.

Walker, K. A., Gottesman, R. F., Wu, A., Knopman, D. S., Gross, A. L., Mosley, T. H., ... \& Windham, B. G. (2019). Systemic inflammation during midlife and cognitive change over 20 years. Neurology, 92(11), 1256-1267.

Zhu, N., Zhang, D., Wang, W., Li, X., Yang, B., Song, J., ... \& Tan, W. (2020). A novel coronavirus from patients with pneumonia in China, 2019. New England Journal of Medicine, 727-733. 